\title{
Resource-Economic Growth Nexus, Role of Govemance, Financial Development, Globalization, and War: A Dynamic Approach
}

\author{
Zahra Jalili+, Mohammad Reza Salmani Bishak', Mohammad Ali Motafakker Azad', \\ Behzad Salmani ${ }^{1}$, Jaafar Haghighat ${ }^{1}$ \\ ${ }^{1}$ University of Tabriz, Iran
}

\begin{abstract}
This study reassesses the resource-economic growth nexus by incorporating several channels. Panel time series techniques are used to analyze panel time series data from 1980 to 2015 in 31 oil-rich countries. The results show that oil rent augments economic growth; thus, oil rent is conducive for, rather than an impediment to, economic growth. The role of governance in economic growth is significant in the examined countries. Financial development is an unimportant channel in the resource-growth nexus because it is often unable to mobilize oil rent from the government to the private sector in oil-rich countries. Globalization is advantageous for countries as it promotes economic growth. Finally, war exerts a significant negative effect on growth in the long term.
\end{abstract}

Keywords: Resource, Economic Growth, Governance, War, Cross-sectionally Augmented Distributed Lag (CS-ARDL) JEL Classifications: C61, F60, G10, H56, O13, O43

Received 5 January 2019, Revised 3 June 2019, Accepted 8 July 2019

\section{Introduction}

The relationship between resources and economic growth is intriguing and controversial. The literature on the natural resource-economic growth, or resource-growth, nexus can be divided into three strands: The first strand argues that resource abundance hinders economiFc growth through rent seeking and the Dutch disease process (Sachs and Warner 1995, 1999, 2001, Gylfason 2001, Mehlum et al. 2006). This argument has been criticized by researchers in the second strand of literature, which argues that the impact of natural resources on economic

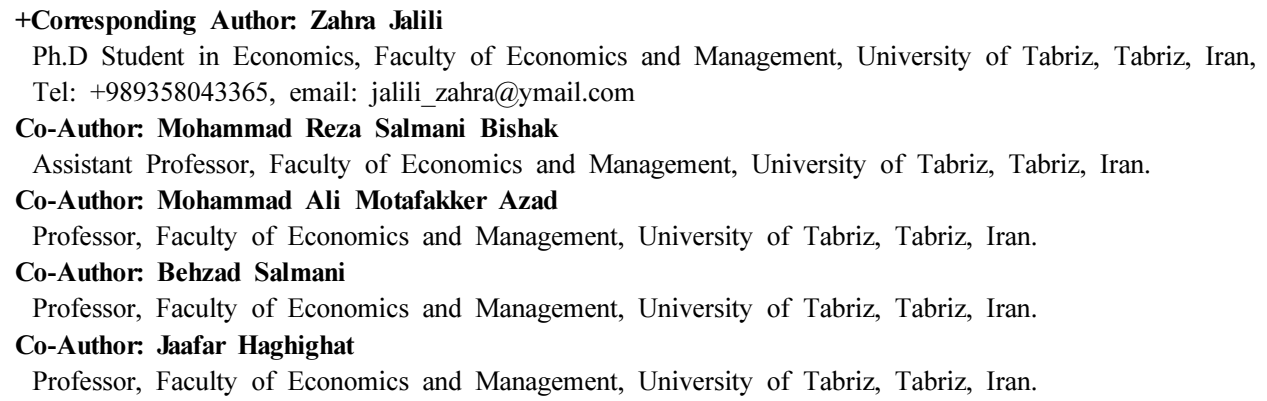


growth is conditional because it depends on the status of governance and other factors (Brunnschweiler 2008, Van der Ploeg 2011, Smith 2015). The third strand of literature argues that resources benefit economic growth (Cavalcanti et al. 2011a, b).

The controversy on whether resource is a curse or a blessing motivated us to reassess the resource-growth nexus. An in-depth examination of the extant literature reveals that the disparities in research findings can be primarily attributed to the hypotheses adopted, variable selection, methodology, and country selection. Many previous studies have assessed the role of natural endowment in economic growth, but disregarded variables such as financial development, globalization, and war. For instance, Van der Ploeg (2011) contended that natural resource can be a curse or a blessing depending on several factors: Developing countries with resource abundance are often incapable of efficiently transforming exhaustible resources into productive assets. This transformation requires a well-functioning financial market. However, the mediating role of financial markets has not been sufficiently addressed in the growth-resource literature (Sachs and Warner 1995, 1999, 2001, Brunnschweiler 2008, Cavalcanti et al. 2011a, b, Bhattacharyya and Hodler 2010, Ebeke et al. 2015).

Although Al-Mamun et al. (2017) resolved a few valid concerns, they overlooked an important variable, namely, the involvement of a country in war. Previous studies have indicated that the abundance of natural resources leads to conflicts or civil wars due to the misdistribution of the benefits of such resources (Collier and Hoeffler 1998 \& 2004). Moreover, resource rent is often abused to finance wars (Collier and Hoeffler 1998 \& 2004, Ross 2004, Lujala et al. 2005). In this situation, a portion of government revenues is spent on war instead of being used for social development.

The interface between the resource-growth nexus and applied econometrics is often idealistic, with pragmatic justification for many studies founded on a feeble theoretical base. Several studies on the resource-growth nexus have employed macro time series data and adopted a static econometric approach to analyze their model (e.g., Brunnschweiler 2008, Smith 2015). However, discovery of finite natural resources is characterized as an economic shock that persists for a long macroeconomic cycle. A static approach fails to consider such an inter-temporal issue in its framework. Moreover, static analyses fail to capture the dynamism of resources in explaining growth. Hence, the validity of their findings is questionable. Apart from using appropriate econometric techniques, several prominent studies have confined their scrutiny to a small frame due to the omission of important determinants that explain the resource-growth paradigm. As a result, the findings of these studies are merely speculative about whether resource is a curse or a blessing to economic development.

The concept of "institution" or "governance" is dynamic. The parameters that set the foundation of the concept of governance or quality of governance and the mechanism through which governance affects economic outcomes change rapidly. Exhaustive research is crucial for oil-rich 
countries to boost their economy by ensuring a sustainable pattern of growth. We aim to provide policy recommendations to this effect.

This work contributes to the development of the economics and governance literature in several ways. First, it overcomes several limitations within the extant literature, such as the use of econometric methods and variables. Second, it addresses cross-sectional and endogeneity bias problems, which have not been considered in other studies. Lastly, the current work considers various mediating factors when explaining the resource-growth nexus.

The remaining paper is structured as follows: Section 2 presents the hypothesis development and literature review. Section 3 introduces the data, descriptive statistics, and methodology used in this study. Section 4 describes the main results on the resource-growth nexus in the examined countries under various hypotheses, and section 5 presents the conclusions.

\section{Literature Review and Hypothesis Development}

\section{A. Resource-growth nexus}

Empirical studies have assessed the impact of natural resources on economic growth, and each study has its own merits in improving our understanding of the resource-growth paradox. The extant literature can be classified into three strands.

The first strand argues that natural resources impede economic growth, and this relationship is called the resource curse paradox (e.g., Gelb 1988, Auty 1990, Sachs and Warner 1995, 1999, 2001, Gylfason 2001, Mehlum et al. 2006, Van der Ploeg 2011, Kim and Lin 2015). Sachs and Warner (2001) argued that countries with abundant natural resources experience sluggish economic growth compared with countries with minimal natural resources.

The second strand argues that resources are important for modern economies, where they are considered an indispensable factor for producing major goods and services. Studies have revealed that resource abundance amplifies economic growth (Alexeev and Conrad 2009, Arezki and Van der Ploeg 2007, Cavalcanti et al. 2011a, b, Smith 2015, James 2015). For instance, Cavalcanti et al. (2011a) reported that the negative association between resource and growth is a methodological choice.

The third strand argues that natural resources can a blessing or a curse depending on the status of governance and other factors (Brunnschweiler 2008, Van der Ploeg 2011, Smith 2015, Al-Mamun et al. 2017). Al-Mamun et al. (2017) argued that the quality of governance is an important driver of economic growth in the long- and short-term economies of oil-rich countries. We thus formulate following hypothesis:

H1: Resource fosters economic growth in oil-rich countries. 


\section{B. Role of quality of govemance in economic growth}

Although governance is the direct driver of economic growth according to neoclassical growth theories, studies have empirically proven that governance plays a mediating role in exerting economic growth. For example, standard neoclassical growth theories (Solow 1956, Cass 1965, Koopmans 1963) argue that disproportionate factor accumulation-which is a direct product of various exogenous factors such as savings rate (Solow 1956), preferences (Cass-Koopmans 1965), technology (Romer 1986), and physical and human capital accumulation (Romer 1986, Lucas 1988) - is the primary cause of income equality among countries. Although theoretical models provide comprehensive insights into the growth paradigm, no reasonable answer has been established to explain the existence of high disparity in income level among countries. North and Thomas (1973) argued that the economic growth difference of countries should be ascribed to the discrepancy in institution or governance: that is, the rules of the game in a society or, more formally, the humanly devised constraints that shape human interaction (North 1990, p.3). Acemoglu et al. $(2001,2005)$ showed that the difference in institutions and quality of governance among countries can explain the differences in the economic performance of countries. Acemoglu and Robinson $(2008,2012)$ emphasized that the quality of political and economic institutions are vital factors that affect economic growth. Government accountability and criticizability are promoted through high-quality governance that protects property rights, perfection of the market, and incentives and innovation of the entrepreneur (North 1990), but also reduces the risk of expropriation and transaction costs (Butkiewicz and Yanikkaya 2006). As a result, a proper political and economic environment can be established through governance; its effect on making investment decisions is thus undeniable.

Different indicators have been used to study the impact of governance on economic growth. For example, Knack and Keefer (1995) considered property rights and contract enforcement as governance indicators and statistically proved the significant positive impact of governance on economic growth. Similarly, Dollar and Kraay (2002) and Rigobon and Rodrik (2005) analyzed the effect of the rule of law on economic growth and observed significant effects. We thus formulate following hypothesis:

H2: Quality of governance fosters economic growth in oil-rich countries.

\section{Role of govemance in resource-growth linkage}

Previous studies have proven that the impact of resources on economic growth depends on the status of governance (Van der Ploeg 2011, Brunnschweiler 2008). Accruing the best potential outcome from natural endowment requires good governance to prevent rent seeking and skewed distribution. Bhattacharyya and Hodler (2010) argued that corruption increases when societies with poor democratic institutions are also resource abundant. Corruption, or poor 
governance, diverts entrepreneurs from productive activities, which, in turn, impede economic growth (Blackburn and Forgues-Puccio 2009). Smith (2015) and Auty (1994) provided a similar notion - that resources can be a curse or a blessing depending on the quality of governance. This background enables us to postulate our third hypothesis:

H3: The impact of natural resources on economic growth is sensitive to the level of governance.

\section{Role of financial development in resource-growth linkage}

The possible role of financial development in economic growth in oil-rich countries can be further substantiated by the fact that these countries are often characterized by a narrow economic base that depends solely on highly depletable resources (Samargandi et al. 2015). Such a narrow economic base that reflects excessive natural resource possession is confirmed by the presence of low financial deepening (Bhattacharyya and Hodler 2014). Financial development can play a vital role in redistributing the revenue from natural resources to the private sector (Demetriades and Hook Law 2006). Financial market development also eliminates frictions in the market, which decreases transaction and information costs; eventually, symmetric information augments investment and economic growth (Goodhart 2004). Given this notable role of financial development, a system with poor governance may obstruct the potential outcome of financial development during market clearing and reducing information asymmetry (Al-Mamun et al. 2017). Despite its notable role, financial development has been overlooked by prior studies (Ross 2001, Sachs and Warner 1995, Mehlum et al. 2006). This scenario contextualizes the joint effect of oil rent and financial development on explaining economic growth in oil-rich economies. We thus formulate following hypothesis:

H4: The impact of oil rent is significant in the presence of high financial development.

\section{E. Role of globalization in resource-growth linkage}

Regarding the importance of economic globalization, we further scrutinize the role of oil rent in enhancing economic growth by sampling the status of the economic globalization index. Globalization is the unification of goods and capital markets across the world by decreasing the barriers of international trade and foreign investment. It promotes the diffusion of technological progress by lowering transport costs, improving information flows across countries, reducing protectionism, and liberalizing foreign investment and migration rules. Improved integration positively affects economic growth (Alcala \& Ciccone 2004, Frankel and Romer 1999, Dreher 2006 and Grossman and Helpman 2015) and the quality of governance (Risse and Sikkink 1999, Boli and Thomas 1999, Al-Marhubi 2004). Thus, an economy with a narrow base that depends on natural resources can be diversified by exploring new market opportunities through globalization. Given the role of globalization, we hypothesize that the role of oil rent 
is significant in countries with a high economic globalization status:

H5: Oil rent is significant in countries with a high economic globalization status.

\section{F. Role of war in resource-growth linkage}

Previous studies have argued that abundance in natural resources leads to conflicts or civil wars due to the misdistribution of the resource benefit (Collier and Hoeffler 1998 \& 2004). Similarly, Le Billon (2001) revealed that natural resources function as a motivational pretext for wars due to a globally skewed distribution of wealth. Several studies have argued that natural resources are often abused to finance wars (Collier and Hoeffler 1998 \& 2004, Ross 2004, Lujala et al. 2005). Pertaining to this thought, Collier and Hoeffler developed greed and grievance theories. Greed theory focuses on people who become rebellious in order to meet financial needs, whereas grievance theory focuses on arising ethnic and religious segregation, political oppression, and discrimination.

This study assumes that resource-based economies suffer from or undergo internal and external conflicts due to rebels and greedy outsiders, and these conflicts appear as substantial economic shocks. Such shocks are profound from the macroeconomic perspective because these economies respond seriously to resource revenue. Therefore, war offers an important context in the resource-growth linkage.

An anecdotal fact shows that the wars in OPEC member countries exert a significant impact on the international oil market, which influences the macroeconomic performance of oil importer and exporter countries. For example, the Iran-Iraq War of 1980 1989 shook the oil market and eventually led to a hike in oil prices in the international market. Therefore, the contextualization of war occurrence is imperative in resource-growth investigations. We thus formulate following hypothesis:

H6: Resource-growth linkage is negatively influenced by the channel of war.

\section{Data and Methodology}

\section{A. Data}

Considering the role of institutions and war in the resource-growth linkage, this study investigated the resource-growth nexus by using panel data of 31 oil-rich countries ${ }^{1)}$ obtained

1) Algeria, Argentina, Bahrain, Bolivia, Brunei, Cameroon, Canada, Colombia, Democratic Republic Congo, Egypt, Ecuador, Gabon, Indonesia, Iran, Iraq, Kuwait, Malaysia, Mexico, Nigeria, Norway, Oman, Qatar, Russia, Saudi Arabia, Syria, Trinidad and Tobago, Tunisia, the United Arab Emirates, the United Kingdom, the United States, and Venezuela. 
from 1980 to 2015. The logarithmic form of real gross domestic product ( $L G D P C$ ) per capita was used as a dependent variable, in line with several studies (e.g., Cavalcanti et al. 2011a $\&$ b, Apergis and Payne 2014, Ebeke et al. 2015). Oil rent was used as one of the independent variables. Governance quality $(Q O G)$ (known as institutional quality), which consists of corruption, law and order, and bureaucracy quality indicators, was derived from the International Country Risk Guide database (Charron et al. 2010). The mean of the three indicators ranges from 0 to $1-\mathrm{A}$ score of 0 indicates the worst $Q O G$, whereas 1 denotes the best $Q O G$. $Q O G$ indicates neutral government institutions and implies that public officials do not grab resources from citizens/cases that are not stipulated prior to implementing any policy or law. The fourth hypothesis focuses on the role of financial development $(F D)$ in the resource-growth linkage. Prior studies have mentioned that financial development plays a major role in economic growth by enhancing resource allocation efficiency and productivity growth (Beck et al. 2000, Wurgler 2000, Deidda 2006, Beck 2009). Further, economic growth causes an increasing demand for credit to support financial development (Calderón and Liu 2003, Ang 2008, Yang and Yi 2008, Rufael 2009, Fowowe 2010, Zhang et al. 2012, Raz 2013). Thus, this study uses the financial development index comprising credit to the private sector and money supply. The fifth hypothesis focuses on the role of globalization in the resource-growth linkage. In this case, the KOF Index of Globalisation measures the economic, social, and political dimensions of globalization (Dreher 2006). The other control variables used in this study were general government final consumption expenditure (\% of GDP) (GOV), gross fixed capital formation (\% of GDP) $(F C F)$ and population growth $(P O P G)$.

Table 1. Descriptive statistics

\begin{tabular}{cccccc}
\hline Variables & $\mathrm{N}$ & Mean & $\mathrm{SD}$ & Min & Max \\
\hline$L G D P C$ & 1116 & 8.999612 & 1.353223 & 5.54952 & 11.6527 \\
$F C F$ & 1116 & 20.18837 & 11.23596 & -61.266 & 59.3061 \\
GOV & 1116 & 16.04993 & 7.696034 & 2.05759 & 76.2221 \\
OILRENT & 1116 & 22.88565 & 1.702165 & 17.94293 & 26.38048 \\
GLO & 1116 & 53.78669 & 16.00416 & -1.7951 & 89.3306 \\
$P G$ & 1116 & 2.321847 & 1.994159 & -3.33945 & 17.6248 \\
$F D$ & 1085 & 43.5753 & 42.10476 & 5.67507 & 247.961 \\
\hline
\end{tabular}

(Note) Table 1 presents the descriptive statistics of the variables for 31 oil-rich countries over 1980 to 2015.

\section{B. Methodology}

Standard panel unit-root approaches assume that each series is cross-sectional independent and no spill-over effect occurs among the cross countries. In practice, cross-sectional dependency arises due to trade, common financial integration, and other unobserved factors (Hsiao 2003, 
Pesaran and Tosetti 2011). Thus, considering cross-section dependency in a panel unit-root test is important when selecting an appropriate technique for model estimation.

We employed the cross-sectional dependence test suggested by Pesaran (2004) to investigate interdependence and the correlation coefficient. The null hypothesis of the cross-sectional dependence test is cross-sectional independence, and the alternative hypothesis is the presence of cross-sectional dependence among units.

$$
C D=\sqrt{2 T /(N(N-1)}\left(\sum_{i=1}^{N-1}\left(\sum_{j=i+1}^{N} \hat{\rho}_{i j}\right)\right.
$$

where, $\hat{\rho}_{i j}=\hat{\rho}_{j i}=\frac{\sum_{t=1}^{T} e_{i t} e_{j t}}{\left(\sum_{t=1}^{T} e_{i t}^{2}\right)^{1 / 2}\left(\sum_{t=1}^{T} e_{j t}^{2}\right)^{1 / 2}}, e_{i t}$ indicates the residuals that originate from the adopted regression, and. In this regression, denotes a vector dimension of independent variables and can include lags of the dependent variable. is the dependent variable for $i$ countries at time $t$. $T$ and $N$ denote the cross section and time dimension, respectively.

In the presence of a cross-sectional dependence problem, any standard panel technique, such as the Levin-Lin-Chu test or Im-Pesaran-Shin (IPS) test, may yield misleading outcomes. To address this problem, Pesaran (2007) introduced the cross-sectional dependence test by combining two unit-root tests, namely, the augmented Dickey-Fuller and IPS tests, and by considering cross-sectional dependence. To estimate the CIPS statistic, an augmented Dickey-Fuller regression is required:

$$
\triangle y_{i t}=\alpha_{i}+k_{i} t+\beta_{i} y_{i t-1}+\gamma_{i} \bar{y}_{t-1}+\varnothing_{i} \triangle \bar{y}_{t}+\varepsilon_{i t}+\cdots
$$

where $\overline{y_{t}}$ shows the mean of $y_{i t}$ for each unit. To investigate stationary variables while considering cross-sectional dependence, the null and alternative hypotheses are $H_{0}: \beta_{i}=0$ and $H_{1}: \beta_{i}<0$, respectively. The CIPS statistics is:

$$
\operatorname{CIPS}(N, T)=\frac{1}{N} \sum_{i=1}^{N} \tau_{i}(N, T)
$$

Notably, $\tau_{i}(N, T)$ denotes the $t$ statistic of $\beta_{i}$.

To select an appropriate framework to estimate models and obtain robust findings, we applied several techniques that can capture heterogeneity, cross-sectional dependence, or both.

Heterogeneity is an important issue to consider due to its potential country-specific effect. Several methods, such as mean group ordinary least squares (OLS) (Pesaran and Smith 1995), 
pooled mean group (Pesaran et al. 1999), panel fully modified OLS (Pedroni 2000), and panel dynamic OLS (Pedroni 2001), have been introduced to solve the heterogeneity problem in panel time series data. However, these techniques are inconsistent when a cross-sectional dependence problem exists (Neal 2015). To address the cross-sectional dependence bias problem, new advanced techniques, such as common correlated effects (Pesaran 2006), common correlated effects pooled, common correlated effects mean group, and augmented mean group (Bond and Eberhardt 2013), have been introduced. Nevertheless, these techniques are consistent only for the static nature of panel time series data with strict heterogeneity. Therefore, other methods, such as the cross-section autoregressive distributed lag (CS-ARDL), have been established.

Chudik and Pesaran (2015) developed the CS-ARDL method for dynamic panels to solve the aforementioned problems. The Equation for this method is:

$$
y_{i, t}=\alpha_{i}+\lambda_{i} y_{i, t-1}+\beta_{i} x_{i, t}+u_{i, t},
$$

where $u_{i, t}$ comprises idiosyncratic error terms assumed to be cross-sectionally and weakly dependent. In addition, the lagged dependent variable is not strictly exogenous; thus, the estimator is inconsistent. To achieve a consistent estimator, $\sqrt[3]{T}$ lags of the cross-section means are added to Equation (4). The following Equation is then derived:

$$
y_{i, t}=a_{i}+\lambda_{i} y_{i, t-1}+\beta_{i} x_{i, t}+\sum_{l=0}^{P T} \dot{\delta}_{i, l} \bar{z}_{t-l}+e_{i, t}
$$

The number of lags is defined by the optimum lag selection criteria (PT) and $\bar{z}_{t}=\left(\bar{y}_{t-1}, \bar{x}_{t}\right)$ in Equation 5. Owing to $\lambda_{i}$ and $\beta_{i}$, we can write $\pi_{i}=\left(\lambda_{i}, \beta_{i}\right)$, where $\alpha_{i}$ country is a specific intercept and $\lambda_{i}$ is the coefficient of the lag of the dependent variable. The Equation further shows that $\delta_{i, l}$ is the coefficient of the autoregressive part and $\bar{z}_{t}$ is the set of mean dependent and independent variables. The mean group estimator in Equation 6 follows:

$$
\hat{\pi}_{M G}=\frac{1}{N} \sum_{i=1}^{N} \hat{\pi}_{i}
$$

In several conditions, such as $(N, T, P T) \Rightarrow \infty$ and full ranking of factor loadings, $\hat{\pi}_{i}$ and $\hat{\pi}_{M G}$ are consistent (Chudik and Pesaran 2015).

The pooled mean group estimator considers long-term homogeneity, whereas the short-term heterogeneous effect of the independent variable is on the dependent variable. Thus, Equation 1 is rewritten as an error correction model: 


$$
\Delta y_{i, t}=\phi_{i}\left(y_{i, t-1}\right)+\theta_{1, i} x_{i, t}+\delta_{0, i}+\delta_{1, i} \Delta x_{i, t}+\epsilon_{i, t},
$$

where $\phi_{i}$ is the error-correction speed and $\theta$ and $\delta$ denote long- and short-term coefficients, respectively. Then, the mean group estimator in the short term is:

$$
\hat{\delta}_{M G}=\frac{1}{N} \sum_{i=1}^{N} \hat{\delta}_{i}
$$

The mean group and pooled mean group estimators are consistent under large $N$ and $T$ conditions. However, a bias may occur in a small sample in dynamic heterogeneous panels. Therefore, Chudik and Pesaran (2015) used the "half-panel" jack knife and recursive mean adjustment to address any bias. The mean group estimators of the jack knife and the recursive mean adjustment are:

$$
\begin{aligned}
& \tilde{\pi}_{M G}=2 \tilde{\pi}_{M G}-\frac{1}{2}\left(\hat{\pi}_{M G}^{a}+\hat{\pi}_{M G}^{b}\right) \\
& \tilde{\omega}_{i t}=\omega_{i t}-\frac{1}{t-1} \sum_{s=1}^{t-1} \omega_{i s},
\end{aligned}
$$

where $\omega_{i t}=\left(y_{i t}, x_{i t}\right)$ and $\hat{\pi}_{M G}^{a}$ and $\hat{\pi}_{M G}^{b}$ denote the mean group estimate of the first and second half of the sample, respectively.

We estimated these models through the CS-ARDL method using Equations 11 to 16, which define the first to sixth hypothesis, respectively:

$$
\begin{aligned}
& \triangle \ln G D P C_{i, t}=\delta_{i}+\phi_{i}\left(\triangle \ln G D P C_{i, t-1}\right)+\theta_{1} F C F_{i, t}+\theta_{2} G O V_{i, t}+\theta_{3} P G_{i, t}+\theta_{4} \ln \left(\operatorname{OILRENT}_{i, t}\right) \\
& +\sum_{j=0}^{q-1} \delta_{1 j}^{i} \triangle F C F_{i, t-j}+\sum_{j=0}^{q-1} \delta_{2 j}^{i} \triangle G O V_{i, t-j}+\sum_{j=0}^{q-1} \delta_{3 j}^{i} \Delta P G_{i, t-j} \\
& +\sum_{j=0}^{q-1} \delta_{4 j}^{i} \Delta \ln \text { OILRENT } T_{i, t-j}+\sum_{1=0}^{P T} \delta_{i, 1}^{\prime} \bar{Z}_{i, t-j}+\epsilon_{i, t} \\
& \triangle \ln G D P C_{i, t}=\delta_{i}+\phi_{i}\left(\triangle \ln G D P C_{i, t-1}\right)+\theta_{1} F C F_{i, t}+\theta_{2} G O V_{i, t}+\theta_{3} P G_{i, t}+\theta_{4} \ln \left(\operatorname{OILRENT}_{i, t}\right) \\
& +\theta_{5} Q O G_{i, t}+\sum_{j=0}^{q-1} \delta_{1 j}^{i} \triangle F C F_{i, t-j}+\sum_{j=0}^{q-1} \delta_{2 j}^{i} \triangle G O V_{i, t-j}+\sum_{j=0}^{q-1} \delta_{3 j}^{i} \triangle P G_{i, t-j} \\
& +\sum_{j=0}^{q-1} \delta_{4 j}^{i} \triangle \ln \text { OILRENT } T_{i, t-j}+\sum_{j=0}^{q-1} \delta_{5 j}^{i} \triangle Q O G_{i, t-j}+\sum_{1=0}^{P T} \delta_{i, 1}^{\prime} \bar{Z}_{i, t-j}+\epsilon_{i, t} \\
& \triangle \ln G D P C_{i, t}=\delta_{i}+\phi_{i}\left(\triangle \ln G D P C_{i, t-1}\right)+\theta_{1} F C F_{i, t}+\theta_{2} G O V_{i, t}+\theta_{3} P G_{i, t}+\theta_{4} \ln \left(\operatorname{OILRENT}_{i, t}\right) \\
& +\theta_{5} Q O G_{i, t}+\theta_{6}(\operatorname{lnOILRENT} * Q O G)_{i, t}+\sum_{j=0}^{q-1} \delta_{1 j}^{i} \triangle F C F_{i, t-j} \\
& +\sum_{j=0}^{q-1} \delta_{2 j}^{i} \triangle G O V_{i, t-j}+\sum_{j=0}^{q-1} \delta_{3 j}^{i} \triangle P G_{i, t-j}+\sum_{j=0}^{q-1} \delta_{4 j}^{i} \triangle \ln O \operatorname{OLRENT} T_{i, t-j} \\
& +\sum_{j=0}^{q-1} \delta_{5 j}^{i} \triangle Q O G_{i, t-j}+\sum_{j=0}^{q-1} \delta_{6 j}^{i} \triangle(\ln O \operatorname{LIRENT} * Q O G)_{i, t-j} \\
& +\sum_{1=0}^{P T} \delta_{i, 1}^{\prime} \bar{Z}_{i, t-j}+\epsilon_{i, t}
\end{aligned}
$$




$$
\begin{aligned}
& \triangle \ln G D P C_{i, t}=\delta_{i}+\phi_{i}\left(\triangle \ln G D P C_{i, t-1}\right)+\theta_{1} F C F_{i, t}+\theta_{2} G O V_{i, t}+\theta_{3} P G_{i, t}+\theta_{4} \ln \left(\operatorname{OILRENT}_{i, t}\right) \\
& +\theta_{5} F D_{i, t}+\theta_{6}(\ln \text { OILRENT * FD })_{i, t}+\sum_{j=0}^{q-1} \delta_{1 j}^{i} \triangle F C F_{i, t-j} \\
& +\sum_{j=0}^{q-1} \delta_{2 j}^{i} \triangle G O V_{i, t-j}+\sum_{j=0}^{q-1} \delta_{3 j}^{i} \triangle P G_{i, t-j} \\
& +\sum_{j=0}^{q-1} \delta_{4 j}^{i} \triangle \ln \text { OILRENT } T_{i, t-j}+\sum_{j=0}^{q-1} \delta_{5 j}^{i} \triangle F D_{i, t-j} \\
& +\sum_{j=0}^{q-1} \delta_{6 j}^{i} \Delta(\ln \text { OILRENT *FD })_{i, t-j}+\sum_{1=0}^{P T} \delta_{i, 1}^{\prime} \bar{Z}_{i, t-j}+\epsilon_{i, t} \\
& \triangle \ln G D P C_{i, t}=\delta_{i}+\phi_{i}\left(\triangle \ln G D P C_{i, t-1}\right)+\theta_{1} F C F_{i, t}+\theta_{2} G O V_{i, t}+\theta_{3} P G_{i, t}+\theta_{4} \ln \left(\operatorname{OILRENT}_{i, t}\right) \\
& +\theta_{5} G L O_{i, t}+\theta_{6}(\operatorname{lnOILRENT} * G L O)_{i, t}+\sum_{j=0}^{q-1} \delta_{1 j}^{i} \triangle F C F_{i, t-j} \\
& +\sum_{j=0}^{q-1} \delta_{2 j}^{i} \triangle G O V_{i, t-j}+\sum_{j=0}^{q-1} \delta_{3 j}^{i} \triangle P G_{i, t-j}+\sum_{j=0}^{q-1} \delta_{4 j}^{i} \triangle \ln \text { OILRENT }_{i, t-j} \\
& +\sum_{j=0}^{q-1} \delta_{5 j}^{i} \Delta G L O_{i, t-j}+\sum_{j=0}^{q-1} \delta_{6 j}^{i} \Delta(\operatorname{lnOILRENT} * G L O)_{i, t-j} \\
& +\sum_{1=0}^{P T} \delta_{i, 1}^{\prime} \bar{Z}_{i, t-j}+\epsilon_{i, t} \\
& +\theta_{5} W A R D U M M Y_{i, t}+\sum_{j=0}^{q-1} \delta_{1 j}^{i} \triangle F C F_{i, t-j}+\sum_{j=0}^{q-1} \delta_{2 j}^{i} \triangle G O V_{i, t-j} \\
& +\sum_{j=0}^{q-1} \delta_{3 j}^{i} \triangle P G_{i, t-j}+\sum_{j=0}^{q-1} \delta_{4 j}^{i} \triangle \ln \text { OILRENT } T_{i, t-j} \\
& +\sum_{j=0}^{q-1} \delta_{5 j}^{i} \triangle W A R D U M M Y_{i, t-j}+\sum_{1=0}^{P T} \delta_{i, 1}^{\prime} \bar{Z}_{i, t-j}+\epsilon_{i, t}
\end{aligned}
$$

\section{Results and Discussions}

\section{A. Cross-sectional dependency and order of integration}

We apply the cross-sectional dependence test developed by Pesaran (2004) to investigate the contemporaneous correlation across the 31 countries. The test is based on the average pair-wise correlations of the OLS residuals from the individual regressions in the panel. The null hypothesis of the cross-sectional dependence test is cross-sectional independence and the alternative hypothesis is the presence of cross-sectional dependence among the selected countries. The result of the cross-sectional dependence test (Table 2) reveal that each series in the panel exhibited cross-sectional dependence. Therefore, the CIPS test for unit roots by Pesaran (2007) was applied. This unit root test allows for cross-sectional dependence. The fourth and fifth columns of Table 1 present the CIPS statistic for the level and the first difference forms of the variable, respectively. Every series was stationary at the level form, except for $L G D P C$ and $F D$. Table 2 shows that all variables were stationary after the first difference. 
Table 2. Cross-sectional dependency test and panel unit-root test

\begin{tabular}{ccccc}
\hline \multicolumn{2}{c}{ Cross Sectional Dependency Test } & & & Panel Unit-Root Test \\
\hline Variables & CD Test & $\rho$ & CIPS (Level) & CIPS (1st Difference) \\
\hline LnGDPC & $39.18^{* * *}$ & 0.610 & -2.390 & $-3.571^{* * *}$ \\
GOV & $9.57^{* * *}$ & 0.364 & $-2.270^{* * *}$ & $-3.831^{* * *}$ \\
$F C F$ & $10.03^{* * *}$ & 0.323 & $-2.408^{* * *}$ & $-3.770^{* * *}$ \\
LnOIL RENT & $94.86^{* * *}$ & 0.733 & $-4.266^{* * *}$ & $-5.909^{* * *}$ \\
POPG & $28.43^{* * *}$ & 0.508 & $-3.322^{* * *}$ & $-4.477^{* * *}$ \\
$F D$ & $20.08^{* * *}$ & 0.477 & -1.761 & $-3.423^{* * *}$ \\
OOG & $10.34^{* * *}$ & 0.451 & $-2.175^{* * *}$ & $-3.548^{* * *}$ \\
GLOBALIZATION & $108.39^{* * *}$ & 0.838 & $-2.033^{*}$ & $-4.015^{* * *}$ \\
\hline
\end{tabular}

(Note) $* * *, * *$, and $*$ indicate the level of significance at $1 \%, 5 \%$, and $10 \%$, respectively.

\section{B. Resource-growth nexus}

Our first hypothesis seeks to determine whether natural resources, particularly oil, are positively or negatively associated with growth. This hypothesis is discussed based on Equation 11. Table 3 shows that the existence of a long-run causality from all explanatory variables to economic growth is confirmed by negative and significant coefficient of error correction term. The findings from the main model report that oil rent was positively and significantly associated with economic growth. This finding coincides with that of several prominent studies documenting that resource abundance amplifies economic growth (Alexeev and Conrad 2009, Arezki and Van der Ploeg 2007, Cavalcanti et al. 2011a, b, Smith 2015, James 2015). For example, Cavalcanti et al. (2011a) refuted the claim that oil abundance negatively affects economic growth and posed a challenge to other studies after obtaining a positive association between natural resources and economic growth in their empirical research. The studies conducted by Alexeev and Conrad (2009), Arezki and Van der Ploeg (2007), Cavalcanti et al. (2011b), and Van der Ploeg and Poelhekke (2010) also questioned the validity of the resource curse paradox of Sachs and Warner $(1995,1999,2001)$. These studies found that oil revenue windfalls do not cause economic growth. Thus, using the negative, but insignificant, coefficient of oil rent in the short term to indicate whether an economy benefits from oil rent yields inconclusive results.

Regarding the control variable in the main model, the long-term coefficient of fixed capital formation was statistically significant at the $1 \%$ level. The estimated coefficient suggests that a one-unit increase in gross fixed capital formation would lead to approximately 0.021 units of increase in economic growth for these countries. The economic reasoning for such a result is appealing. Fixed capital formation does lead to an optimum combination of labor and capital that, in turn, increases the productivity of labor, as argued in the Cobb-Douglas production function. Our findings coincide with the findings of Arcand et al. (2014), Loayza and Ranciere (2006), Wu et al. (2010), and Samargandi et al. (2015). 
In line with our postulation in the introduction section, Table 3 reports the negative and significant role of government expenditure in the long and short terms because high government expenditure is a proxy for less space for the efficient development of the private sector and for a high level of corruption (Goel and Nelson 1998, Montinola and Jackman 2002). This condition results in reduced economic outputs (Barro 1990, Barro 1999, Loayza and Ranciere 2006). Furthermore, high government expenditure is a proxy for increased tax burden, which leads to a reduction in private spending and investment. This result indicates that a high population growth is a burden on the economy.

Table 3. Resource-growth nexus

\begin{tabular}{|c|c|}
\hline Variables & $\begin{array}{c}\text { Oil Rent (Mail Model) } \\
\text { CS-ARDL }\end{array}$ \\
\hline & Long run \\
\hline \multirow[t]{2}{*}{$F C F$} & $0.021 * * *$ \\
\hline & $(0.003)$ \\
\hline \multirow[t]{2}{*}{$G O V$} & $-0.023 * * *$ \\
\hline & $(0.005)$ \\
\hline \multirow[t]{2}{*}{$P G$} & $-0.337 * * *$ \\
\hline & $(0.043)$ \\
\hline \multirow[t]{3}{*}{ OILRENT } & $0.016^{* *}$ \\
\hline & $(0.007)$ \\
\hline & Short run \\
\hline \multirow[t]{2}{*}{ Error Correction } & $-0.049 * * *$ \\
\hline & $(0.009)$ \\
\hline \multirow[t]{2}{*}{ D.FCF } & $0.004 * * *$ \\
\hline & $(0.002)$ \\
\hline \multirow[t]{2}{*}{ D. GOV } & $-0.005 * * *$ \\
\hline & $(0.002)$ \\
\hline \multirow[t]{2}{*}{$D . P G$} & 0.064 \\
\hline & $(0.062)$ \\
\hline \multirow[t]{2}{*}{ D.OILRENT } & $-0.002 * *$ \\
\hline & $(0.001)$ \\
\hline \multirow[t]{2}{*}{ Constant } & $-0.306^{* * *}$ \\
\hline & $(0.064)$ \\
\hline Observations & 1085 \\
\hline Number of groups & 31 \\
\hline CD Test & 66.72 \\
\hline
\end{tabular}

(Note) $* * *, * *$, and $*$ indicate the level of significance at $1 \%, 5 \%$, and $10 \%$, respectively. The numbers in parentheses show the standard errors.

\section{Govemance and economic growth}

In the second hypothesis, the quality of governance fosters economic growth, which is formulated by Equation 12. The coefficient of quality of governance is positive and significant 
in the long term. In-depth examination of the coefficients suggests that the quality of governance is the most important determinant of economic growth for the sample countries in the short and long terms. The estimated coefficient suggests that a unit increase in the quality of governance would lead to an approximately 0.771 unit increase in economic growth in the examined countries in the long term.

Our result is consistent with those of previous studies, such as Demetriades and Hook Law (2006), for different countries, except for the least-developed ones. However, the findings of Demetriades and Hook Law (2006) will not apply if we correct the cross-sectional bias for their sample countries. Therefore, our finding is robust and superior to the conclusions of Demetriades and Hook Law (2006).

The main results in Table 4 report evidence indicating that the quality of governance is important for economic growth in oil-rich economies. Given that most oil-rich countries in the world are members of OPEC, our empirical findings on the positive role of quality of

Table 4. Growth and governance

\begin{tabular}{|c|c|}
\hline Variables & $\begin{array}{c}\text { Governance } \\
\text { CS-ARDL }\end{array}$ \\
\hline & Long run \\
\hline \multirow[t]{2}{*}{$F C F$} & $0.068 * * *$ \\
\hline & $(0.015)$ \\
\hline \multirow[t]{2}{*}{ GOV } & $-0.117 * * *$ \\
\hline & $(0.027)$ \\
\hline \multirow[t]{2}{*}{$P G$} & $-1.169 * * *$ \\
\hline & $(0.189)$ \\
\hline \multirow[t]{3}{*}{$Q O G$} & $0.771^{*}$ \\
\hline & $(0.420)$ \\
\hline & Short run \\
\hline \multirow[t]{2}{*}{ Error Correction } & $-0.015 * * *$ \\
\hline & $(0.004)$ \\
\hline \multirow[t]{2}{*}{ D.FCF } & $0.004 * * *$ \\
\hline & $(0.001)$ \\
\hline \multirow[t]{2}{*}{ D.GOV } & $-0.005 * * *$ \\
\hline & $(0.002)$ \\
\hline \multirow[t]{2}{*}{$D . P G$} & 0.060 \\
\hline & $(0.047)$ \\
\hline \multirow[t]{2}{*}{ D. $Q O G$} & 0.050 \\
\hline & $(0.077)$ \\
\hline \multirow[t]{2}{*}{ Constant } & $0.171 * * *$ \\
\hline & $(0.038)$ \\
\hline Observations & 1085 \\
\hline Number of groups & 31 \\
\hline CD Test & 13.48 \\
\hline
\end{tabular}

(Note) $* * *, * *$, and $*$ indicate the level of significance at $1 \%, 5 \%$, and $10 \%$, respectively. The numbers in parentheses show the standard errors. 
governance are expected.

\section{Growth and resource: role of governance}

In the third hypothesis, oil rent combined with governance significantly affects economic growth, which is formulated by Equation 13. This hypothesis is confirmed because the coefficient of oil rent and governance interaction is positive and significant for the long term. Thus, we established the main link between oil rent and economic growth in oil-rich countries by clustering the sample into high and low governance.

Table 5 shows that the coefficient of oil rent was positive and significant in the long term in the case of low-governance countries. Our finding coincides with the argument that the relationship between resource and economic growth is manifested through governance status (Van der Ploeg 2011, Brunnschweiler 2008). Van der Ploeg (2011) added that natural resources can be a "curse" or a "blessing" depending on various factors, such as rent seeking and violence, institutional quality, and financial systems. Several other studies have also argued that poor institutional quality is the outcome of natural resources because dependence on natural resources leads to market and institutional failures that incur sluggish economic growth (Auty 1994, Bhattacharyya and Hodler 2010, Gylfason 2001, Sachs and Warner 1995).

\section{E. Growth and resource: role of financial development}

The fourth hypothesis discussed the role of financial development on the resource-growth nexus, which is formulated by Equation 14. In this hypothesis, the impact of oil rent is significant in the presence of high financial development. To examine this hypothesis, we used financial development $(F D)$ as the regressor in the model and interaction between $F D$ and oil rent. To check for robustness, we split the sample into high and low levels of financial development. Table 6 shows that the error correction coefficients for all the estimated models are negative and statistically significant and there is a long-run relationship between economic growth and its predictors. The result indicates that financial development is significant in the long term. The coefficient of interaction variable (FD $\times$ Oil Rent) is negative and insignificant, which indicates that oil rent and financial development jointly play an insignificant role in promoting economic growth. Despite the plausible role of financial development in mobilizing the oil rent in the private sector for the overall economy to flourish, our result nullified the hypothesis. The result can be explained as follows: In the presence of an authoritarian government structure and narrow-base economies, oil rent is confined within the hands of a few. Hence, financial development is often unable to mobilize oil rent from the government to the private sector. Likewise, the result reveals a positive and significant coefficient of oil rent in the long-term economies of low and high financially developed countries. 
Table 5. Growth and resource: role of governance

\begin{tabular}{|c|c|c|c|}
\hline Variables & $\begin{array}{c}\text { Oil Rent and Governance } \\
\text { CS-ARDL }\end{array}$ & $\begin{array}{c}\text { Low Governance } \\
\text { CS-ARDL }\end{array}$ & $\begin{array}{l}\text { High Governance } \\
\text { CS-ARDL }\end{array}$ \\
\hline & Long run & Long run & Long run \\
\hline \multirow[t]{2}{*}{$F C F$} & $0.017 * * *$ & $0.019 * * *$ & 0.010 \\
\hline & $(0.003)$ & $(0.006)$ & $(0.007)$ \\
\hline \multirow[t]{2}{*}{$G O V$} & $-0.027 * * *$ & $0.036^{* * *}$ & $-0.087 * * *$ \\
\hline & $(0.005)$ & $(0.009)$ & $(0.015)$ \\
\hline \multirow[t]{2}{*}{$P G$} & $-0.145^{* * *}$ & $-1.136^{* * *}$ & $-0.584 * * *$ \\
\hline & $(0.034)$ & $(0.141)$ & $(0.075)$ \\
\hline \multirow[t]{2}{*}{ OILRENT } & -0.091 & $0.033^{*}$ & 0.026 \\
\hline & $(0.027)$ & $(0.019)$ & $(0.017)$ \\
\hline \multirow[t]{2}{*}{$Q O G$} & -0.850 & & \\
\hline & $(0.682)$ & & \\
\hline \multirow[t]{3}{*}{$O I L R E N T^{*} Q O G$} & $0.053^{*}$ & & \\
\hline & $(0.031)$ & & \\
\hline & Short run & Short run & Short run \\
\hline \multirow{2}{*}{ Error Correction } & $-0.043 * * *$ & $-0.030 * *$ & $-0.031 * * *$ \\
\hline & $(0.013)$ & $(0.012)$ & $(0.007)$ \\
\hline \multirow[t]{2}{*}{$D . F C F$} & $0.004 * * *$ & $0.004 * * *$ & $0.005^{* *}$ \\
\hline & $(0.001)$ & $(0.001)$ & $(0.002)$ \\
\hline \multirow[t]{2}{*}{ D.GOV } & $-0.006^{* * *}$ & $-0.005 * *$ & $-0.007 * * *$ \\
\hline & $(0.002)$ & $(0.002)$ & $(0.002)$ \\
\hline \multirow[t]{2}{*}{$D . P G$} & 0.036 & 0.099 & -0.003 \\
\hline & $(0.065)$ & $(0.132)$ & $(0.030)$ \\
\hline \multirow[t]{2}{*}{ D.OILRENT } & 0.010 & $0.002 *$ & 0.001 \\
\hline & $(0.006)$ & $(0.001)$ & $(0.001)$ \\
\hline \multirow[t]{2}{*}{ D. $Q O G$} & -0.374 & & \\
\hline & $(0.360)$ & & \\
\hline \multirow[t]{2}{*}{ D.OILRENT ${ }^{*} Q O G$} & 0.018 & & \\
\hline & $(0.016)$ & & \\
\hline \multirow[t]{2}{*}{ Constant } & -0.484 & $0.255^{* * *}$ & $0.363 * * *$ \\
\hline & $(0.144)$ & $(0.096)$ & $(0.077)$ \\
\hline Observations & 1085 & 560 & 510 \\
\hline Number of groups & 31 & 16 & 15 \\
\hline CD Test & 98.38 & 20.52 & 21.19 \\
\hline
\end{tabular}

(Note) $* * *, * *$, and $*$ indicate the level of significance at $1 \%, 5 \%$, and $10 \%$, respectively. The numbers in parentheses show the standard errors. 
Table 6. Growth and resource: role of financial development

\begin{tabular}{|c|c|c|c|}
\hline Variables & $\begin{array}{l}\text { Oil Rent and FD } \\
\text { CS-ARDL }\end{array}$ & $\begin{array}{c}\text { Low Financial Development } \\
\text { CS-ARDL }\end{array}$ & $\begin{array}{c}\text { High Financial Development } \\
\text { CS-ARDL }\end{array}$ \\
\hline \multirow{3}{*}{$F C F$} & Long run & Long run & Long run \\
\hline & $-0.033^{* * *}$ & $0.067 * * *$ & 0. $039 * * *$ \\
\hline & $(0.010)$ & $(0.017)$ & $(0.014)$ \\
\hline \multirow[t]{2}{*}{$G O V$} & $-0.242 * * *$ & $-0.106^{* * *}$ & $-0.086^{* *}$ \\
\hline & $(0.053)$ & $(0.027)$ & $(0.027)$ \\
\hline \multirow[t]{2}{*}{$P G$} & $-1.468 * * *$ & $-1.073 * * *$ & $-0.605 * * *$ \\
\hline & $(0.368)$ & $(0.200)$ & $(0.125)$ \\
\hline \multirow[t]{2}{*}{ OILRENT } & 0.073 & $0.058^{* *}$ & $0.040^{* *}$ \\
\hline & $(0.056)$ & $(0.028)$ & $(0.020)$ \\
\hline \multirow[t]{2}{*}{$F D$} & $0.077 * * *$ & & \\
\hline & $(0.030)$ & & \\
\hline \multirow[t]{3}{*}{$O I L R E N T^{*} F D$} & -0.001 & & \\
\hline & $(0.001)$ & & \\
\hline & Short run & Short run & Short run \\
\hline \multirow[t]{2}{*}{ Error Correction } & $-0.010 * *$ & $-0.016^{* * *}$ & $-0.022 * * *$ \\
\hline & $(0.005)$ & $(0.005)$ & $(0.005)$ \\
\hline \multirow[t]{2}{*}{ D.FCF } & $0.004 * * *$ & $0.005 * * *$ & $0.005 * * *$ \\
\hline & $(0.001)$ & $(0.002)$ & $(0.001)$ \\
\hline \multirow[t]{2}{*}{ D. GOV } & $-0.004 *$ & $-0.004 * *$ & $-0.013 * * *$ \\
\hline & $(0.001)$ & $(0.002)$ & $(0.003)$ \\
\hline \multirow[t]{2}{*}{$D . P G$} & -0.015 & 0.065 & -0.031 \\
\hline & $(0.044)$ & $(0.067)$ & $(0.023)$ \\
\hline \multirow[t]{2}{*}{ D.OILRENT } & 0.001 & 0.0001 & $-0.003 * * *$ \\
\hline & $(0.002)$ & $(0.002)$ & $(0.001)$ \\
\hline \multirow[t]{2}{*}{ D.FD } & 0.001 & & \\
\hline & $(0.004)$ & & \\
\hline \multirow[t]{2}{*}{ D.OILRENT*FD } & -0.0001 & & \\
\hline & $(0.0002)$ & & \\
\hline \multirow[t]{2}{*}{ Constant } & $0.064 * *$ & $0.138^{* * *}$ & $0.271 * * *$ \\
\hline & $(0.028)$ & $(0.044)$ & $(0.069)$ \\
\hline Observations & 1085 & 770 & 315 \\
\hline Number of Groups & 31 & 22 & 9 \\
\hline CD Test & 23.90 & 19.32 & 9.56 \\
\hline
\end{tabular}

(Note) $* * * * *$, and $*$ indicate the level of significance at $1 \%, 5 \%$, and $10 \%$, respectively. The numbers in parentheses show the standard errors. 


\section{F. Economic growth and resource: role of globalization}

We also hypothesized in our framework that the role of oil rent should be significant in countries with high economic globalization, which is formulated by Equation 15. Globalization is an essential process of interconnections and interdependencies among countries, and its primary manifold domain includes political, economic, and social dimensions. It has been evolving within and has been reshaped by multiple arenas of development, namely, degree of trade openness, marketing activities, business operations, minimizing transport and transaction costs, and advancement in technological diffusion over time (Frankel and Romer 1999). Therefore, globalization is an important channel through which oil rent can boost the economy.

The existence of a long-run relationship between economic growth and its predictors is confirmed by the negative and significant coefficient of error correction. The second column of Table 7 indicates that the direct impact of oil rent and the coefficient of the joint variable (oil rent $\times$ globalization) is positive and significant in the long term. To check for robustness, we split the sample into higher and lower globalization. Table 7 shows that the coefficient of oil rent is positive and significant in the low- and high-globalization countries. Our robust analysis indicates that the globalization process leads to economic growth. This finding can be explained by the fact that globalization necessarily promotes economic growth. Similarly, Wei (2006) documented that globalization can lead to economic growth only if a threshold level of institutional quality exists, which would lead to a desirable composition of capital inflows for the capital-importing country.

\section{G. Economic growth and resource: role of war}

In the sixth hypothesis, resource-based economies suffer from or undergo internal and external conflicts due to rebels and greedy outsiders. These conflicts appear as substantial economic shocks, which is formulated by Equation 16. Such shocks are profound from the macroeconomic perspective because these economies respond highly to resource revenue. Therefore, war offers important contextualization in the resource-growth linkage. In examining the hypothesis, we considered several war dummy variables, such as the Iran-Iraq, Iraq-US, Libya-US, and Iraq-Kuwait wars. We thus measured the direct impact of war. Table 8 shows that the coefficients of the Iran-Iraq, Iraq-US, and Libya-US war dummies were negative and significant in the long term. The impact of oil rent was positive and significant in the long term. Thus, our findings are in line with those of prior studies, such as Collier and Hoeffler (1998, 2004), Ross (2004), Lujala et al. (2005), and McKillop (2004). 
Table 7. Growth and resource: role of globalization

\begin{tabular}{|c|c|c|c|}
\hline Variables & $\begin{array}{c}\text { Oil Rent and Globalization } \\
\text { CS-ARDL }\end{array}$ & $\begin{array}{c}\text { Low Globalization } \\
\text { CS-ARDL }\end{array}$ & $\begin{array}{c}\text { High Globalization } \\
\text { CS-ARDL }\end{array}$ \\
\hline & Long run & Long run & Long run \\
\hline \multirow[t]{2}{*}{$F C F$} & $0.030 * * *$ & $0.022 * * *$ & $0.114 * *$ \\
\hline & $(0.003)$ & $(0.005)$ & $(0.019)$ \\
\hline \multirow[t]{2}{*}{$G O V$} & $-0.016 * * *$ & 0.014 & $0.112^{* *}$ \\
\hline & $(0.002)$ & $(0.010)$ & $(0.037)$ \\
\hline \multirow{2}{*}{$P G$} & $-0.340 * * *$ & $-1.269 * * *$ & $0.980 * * *$ \\
\hline & $(0.048)$ & $(0.132)$ & $(0.156)$ \\
\hline \multirow[t]{2}{*}{ OILRENT } & $0.051^{*}$ & $0.031 * * *$ & $0.082 * *$ \\
\hline & $(0.030)$ & $(0.012)$ & $(0.044)$ \\
\hline \multirow[t]{2}{*}{$Q L O$} & -0.012 & & \\
\hline & $(0.013)$ & & \\
\hline \multirow[t]{3}{*}{ OILRENT* $Q L O$} & $0.001 * *$ & & \\
\hline & $(0.001)$ & & \\
\hline & Short run & Short run & Short run \\
\hline \multirow{2}{*}{ Error Correction } & $-0.054 * * *$ & $-0.031 * * *$ & $-0.012 * * *$ \\
\hline & $(0.018)$ & $(0.009)$ & $(0.004)$ \\
\hline \multirow[t]{2}{*}{ D.FCF } & $0.003 * * *$ & $0.003 * * *$ & $0.006^{* *}$ \\
\hline & $(0.001)$ & $(0.001)$ & $(0.002)$ \\
\hline \multirow[t]{2}{*}{ D.GOV } & $-0.006^{* * *}$ & $-0.006 * *$ & -0.005 \\
\hline & $(0.002)$ & $(0.002)$ & $(0.003)$ \\
\hline \multirow[t]{2}{*}{$D . P G$} & 0.098 & 0.126 & -0.037 \\
\hline & $(0.071)$ & $(0.116)$ & $(0.024)$ \\
\hline \multirow[t]{2}{*}{ D.OILRENT } & 0.001 & 0.002 & $-0.004 * * *$ \\
\hline & $(0.011)$ & $(0.002)$ & $(0.001)$ \\
\hline \multirow[t]{2}{*}{ D. $Q L O$} & -0.001 & & \\
\hline & $(0.004)$ & & \\
\hline \multirow[t]{2}{*}{ D.OILRENT* $Q L O$} & -0.0001 & & \\
\hline & $(0.0003)$ & & \\
\hline \multirow[t]{2}{*}{ Constant } & $-0.144 * * *$ & $0.293 * * *$ & $0.255 * * *$ \\
\hline & $(0.048)$ & $(0.085)$ & $(0.095)$ \\
\hline Observations & 1085 & 630 & 442 \\
\hline Number of Groups & 31 & 18 & 13 \\
\hline CD Test & 67.42 & 28.51 & 11.18 \\
\hline
\end{tabular}

(Note) $* * *, * *$, and $*$ indicate the level of significance at $1 \%, 5 \%$, and $10 \%$, respectively. The numbers in parentheses show the standard errors. 
Table 8. Growth and resource: role of war

\begin{tabular}{|c|c|c|c|c|}
\hline Variables & $\begin{array}{c}\text { (Iran-Iraq War) } \\
\text { CS-ARDL } \\
\end{array}$ & $\begin{array}{c}\text { (Iraq-US War) } \\
\text { CS-ARDL }\end{array}$ & $\begin{array}{c}\text { (Libya-US War) } \\
\text { CS-ARDL }\end{array}$ & $\begin{array}{c}\text { (Iraq-Kuwait War) } \\
\text { CS-ARDL }\end{array}$ \\
\hline \multirow{3}{*}{$F C F$} & Long run & Long run & Long run & Long run \\
\hline & $0.007 * * *$ & $0.032 * * *$ & $0.008 * * *$ & $0.021 * * *$ \\
\hline & $(0.002)$ & $(0.006)$ & $(0.002)$ & $(0.004)$ \\
\hline \multirow[t]{2}{*}{ GOV } & -0.004 & -0.001 & 0.004 & $-0.014^{*}$ \\
\hline & $(0.004)$ & $(0.009)$ & $(0.004)$ & $(0.008)$ \\
\hline \multirow[t]{2}{*}{$P G$} & $-0.281 * * *$ & $-1.154 * * *$ & $-0.376 * * *$ & $-1.261 * * *$ \\
\hline & $(0.049)$ & $(0.128)$ & $(0.047)$ & $(0.117)$ \\
\hline \multirow[t]{2}{*}{ OILRENT } & $0.015^{* * *}$ & $0.034 * * *$ & $0.019^{*}$ & $0.034^{*}$ \\
\hline & $(0.005)$ & $(0.012)$ & $(0.011)$ & $(0.020)$ \\
\hline \multirow[t]{2}{*}{ Iran-Iraq War Dummy } & $-0.123 * * *$ & & & \\
\hline & $(0.029)$ & & & \\
\hline \multirow[t]{2}{*}{ Iraq-US War Dummy } & & $-0.127 * * *$ & & \\
\hline & & $(0.049)$ & & \\
\hline \multirow[t]{2}{*}{ Libya-US War Dummy } & & & $-0.130^{* *}$ & \\
\hline & & & $(0.065)$ & \\
\hline \multirow[t]{3}{*}{ Iraq-Kuwait War Dummy } & & & & -0.023 \\
\hline & & & & $(0.072)$ \\
\hline & Short run & Short run & Short run & Short run \\
\hline \multirow[t]{2}{*}{ Error Correction } & $-0.066 * * *$ & $-0.023^{* * *}$ & $-0.059 * * *$ & $-0.023 * * *$ \\
\hline & $(0.016)$ & $(0.002)$ & $(0.020)$ & $(0.006)$ \\
\hline \multirow[t]{2}{*}{ D.FCF } & $0.005^{* * *}$ & $0.004 * * *$ & $0.004 * * *$ & $0.005 * * *$ \\
\hline & $(0.001)$ & $(0.001)$ & $(0.001)$ & $(0.001)$ \\
\hline \multirow[t]{2}{*}{ D.GOV } & $-0.007 * * *$ & $-0.006^{* * *}$ & $-0.006^{* * *}$ & $-0.007 * * *$ \\
\hline & $(0.002)$ & $(0.002)$ & $(0.002)$ & $(0.002)$ \\
\hline \multirow[t]{2}{*}{$D . P G$} & 0.044 & 0.060 & 0.050 & 0.078 \\
\hline & $(0.069)$ & $(0.045)$ & $(0.071)$ & $(0.069)$ \\
\hline \multirow[t]{2}{*}{ D.OILRENT } & 0.001 & 0.002 & 0.0001 & 0.0004 \\
\hline & $(0.001)$ & $(0.001)$ & $(0.001)$ & $(0.001)$ \\
\hline \multirow[t]{2}{*}{ D.Iran-Iraq War Dummy } & 0.005 & & & \\
\hline & $(0.007)$ & & & \\
\hline \multirow[t]{2}{*}{ D.Iraq-US War Dummy } & & -0.011 & & \\
\hline & & $(0.010)$ & & \\
\hline \multirow[t]{2}{*}{ D.Libya-US War Dummy } & & & $0.007 * * *$ & \\
\hline & & & $(0.003)$ & \\
\hline \multirow[t]{2}{*}{ D.Iraq-Kuwait War Dummy } & & & & $0.012 * *$ \\
\hline & & & & $(0.006)$ \\
\hline \multirow[t]{2}{*}{ Constant } & $0.193^{* * *}$ & $0.276^{* * *}$ & $0.227 * * *$ & $0.230 * * *$ \\
\hline & $(0.052)$ & $(0.046)$ & $(0.080)$ & $(0.054)$ \\
\hline Observations & 1085 & 1085 & 1085 & 1085 \\
\hline Number of groups & 31 & 31 & 31 & 31 \\
\hline CD Test & 84.00 & 29.86 & 68.06 & 29.19 \\
\hline
\end{tabular}

(Note) $* * *, * *$, and $*$ indicate the level of significance at $1 \%, 5 \%$, and $10 \%$, respectively. The numbers in parentheses show the standard errors. 


\section{Conclusion}

This study obtained several interesting results by scrutinizing the resource-growth nexus and considering several channels in the context of 31 oil-rich countries. By applying panel time series techniques and the CS-ARDL approach, we resolved cross-sectional dependence and heterogeneous problems.

This study found that oil rent augments economic growth. Thus, it is a blessing rather than a curse. The role of governance effectively explains economic growth in the examined countries. Interestingly, oil rent plays a positive and significant role in economic growth in low-governance countries, whereas financial development is not an important channel in the resource-growth nexus. We further reveal that globalization is also important within this nexus, but war exerts a negative and significant impact on growth only in the long term. We thus conclude that resources can be a curse or a blessing depending on governance, financial development, globalization, and war experience.

\section{References}

Acemoglu, D., and Robinson, J. A. (2008). "The Role of Institutions in Growth and Development." The International Bank for Reconstruction and Development/ The World Bank Working Paper No. 10. Acemoglu, D., and Robinson J. A. (2012). Why Nations Fail: The Origins of Power, Prosperity, and Poverty. New York: Crown Business.

Acemoglu, D., Johnson, S., and Robinson, J. A. (2001). "The Colonial Origins of Comparative Development." American Economic Review 91, no. 5, 1369-1401.

Acemoglu, D., Johnson, S., and Robinson, J. A. (2005). "The rise of Europe: Atlantic trade, institutional change, and economic growth." The American Economic Review 95, no. 3, 546-579.

Alcalá, F., and Ciccone, A. (2004). "Trade and productivity." The Quarterly journal of economics 119, no. 2, 613-646.

Alexeev, M., and Conrad, R. (2009). "The elusive curse of oil." The Review of Economics and Statistics 91, no. 3, 586-598.

Al-Mamun, M., Sohag, K., and Hassan, M. K. (2017). "Governance, resources and growth.” Economic Modelling 63, 238-261.

Al-Marhubi, F. (2004). "The Determinants of Governance: A Cross-Country Analysis." Contemporary Economic Policy 22, 394-406.

Ang, J. (2008). "What are the mechanisms linking financial development and economic growth in Malaysia?." Economic Modelling 25, 38-53.

Apergis, N., and Payne, J. E. (2014). "Renewable energy, output, $\mathrm{CO}_{2}$ emissions, and fossil fuel prices in Central America: evidence from a nonlinear panel smooth transition vector error correction model.” 
Energy Economics 42, 226-232.

Arcand, J. L., Berkes, E., and Panizza, U. (2014). Finance and economic development in a model with credit rationing. In The Social Value of the Financial Sector: Too Big to Fail or Just Too Big? World Scientific, 67-80.

Arezki, R., and Van der Ploeg, R. (2007). Can the natural resource curse be turned into a blessing? The role of trade policies and institutions. IMF Working Papers, 1-34.

Auty, R. M. (1990). Resource-based industrialization: sowing the oil in eight developing countries. Business \& Economics, Oxford University Press, New York.

Auty, R. M. (1994). "The resource curse thesis: Minerals in Bolivian development, 1970-90." Singapore Journal of Tropical Geography 15, no. 2, 95-111.

Barro, R. J. (1990). "Government spending in a simple model of endogenous growth.” Journal of political economy 98(5, Part 2), 103-125.

Barro, R. J. (1999). "Determinants of democracy." Journal of Political economy 107, no. S6, 158-183.

Beck, T. (2009). The Econometrics of Finance and Growth. Handbook of Econometrics, eds. T. Mills \& K. Patterson. Chapter 2. Palgrave Macmillan.

Beck, T., Levine, R., and Loayza, N. (2000). "Finance and the sources of growth." Journal of Financial Economics 58, 261-300.

Bhattacharyya, S., and Hodler, R. (2010). "Natural resources, democracy and corruption." European Economic Review 54, 608-621.

Bhattacharyya, S., and Hodler, R. (2014). "Do natural resource revenues hinder financial development? The role of political institutions." World Development 57, 101-113.

Blackburn, K., and Forgues-Puccio, G. F. (2009). "Why is corruption less harmful in some countries than in others?." Journal of Economic Behavior \& Organization 72, no. 3, 797-810.

Boli, J., and Thomas, G. M. (1999). Constructing World Culture: International Nongovernmental Organizations since 1875. Stanford University Press.

Bond, S., and Eberhardt, M. (2013). Accounting for unobserved heterogeneity in panel time series models. Nuffield College, University of Oxford, mimeo.

Brunnschweiler, C. N. (2008). "Cursing the blessings? Natural resource abundance, institutions, and economic growth." World development 36, no. 3, 399-419.

Butkiewicz, J. L., and Yanikkaya, H. (2006). "Institutional quality and economic growth: Maintenance of the rule of law or democratic institutions, or both." Economic Modelling 23, 648-661.

Calderón, C., and Liu, L. (2003). "The direction of causality between financial development and economic growth." Journal of Development Economics 72, no. 1, 321-334.

Cass, D. (1965). "Optimum growth in an aggregative model of capital accumulation." The Review of Economic Studies 32, no. 3, 233-240.

Cavalcanti, T. V. D. V., Mohaddes, K., and Raissi, M. (2011a). "Growth, development and natural resources: New evidence using a heterogeneous panel analysis." The Quarterly Review of Economics and Finance 51, no. 4, 305-318.

Cavalcanti, T. V. D. V., Mohaddes, K., and Raissi, M. (2011b). "Does oil abundance harm growth?." Applied Economics Letters 18, no. 12, 1181-1184. 
Charron, N., Lapuente, V., and Rothstein, B. (2010). Measuring the Quality of Government and Subnational Variation. Report for the European Commission Directorate-General Regional Policy Directorate Policy Development. Brussels: European Union.

Chudik, A., and Pesaran, M. H. (2015). "Large panel data models with cross-sectional dependence: A survey." In The Oxford Handbook of Panel Data, ed. B. H. Baltagi, chap. 1, 2-45. Oxford: Oxford University Press.

Collier, P., and Hoeffler, A. (1998). "On economic causes of civil war." Oxford economic papers 50, no. 4, 563-573.

Collier, P., and Hoeffler, A. (2004). "Greed and grievance in civil war." Oxford Economic Papers 56, 563-595.

Deidda, L. (2006). "Interaction between economic and financial development." Journal of Monetary Economics 53, 233-248.

Demetriades, P., and Hook Law, S. (2006). "Finance, institutions and economic development." International journal of finance \& economics 11, no. 3, 245-260.

Dollar, D., and Kraay, A. (2002). "Growth is good for the poor." Journal of Economic Growth 7, 195-225.

Dreher, A. (2006). "Dose globalization affect growth? Evidence from a new index of globalization." Applied Economics 38, no. 10, 1091-1110.

Ebeke, C., Omgba, L. D., and Laajaj, R. (2015). "Oil, governance and the (mis) allocation of talent in developing countries." Journal of Development Economics 114, 126-141.

Fowowe, B. (2010). "The finance-growth nexus in Sub-Saharan Africa: panel cointegration and causality tests." Journal of International Development 23, 220-239.

Frankel, J. A. and Romer, D. (1999). "Does trade cause growth?." American economic review 89, no. 3, 379-399.

Gelb, A. H. (1988). Windfall Gains: Blessing or Curse?. New York: Oxford University Press.

Goel, R. K., and Nelson, M. A. (1998). "Corruption and government size: A disaggregated analysis." Public Choice 97, no. 1-2, 107-120.

Goodhart, C. A. E. (2004). Some new directions for financial stability? (Vol. 27). Bank for International Settlements.

Grossman, G. M., and Helpman, E. (2015). "Globalization and growth." American Economic Review 105 , no. $5,100-104$.

Gylfason, T. (2001). "Natural resources, education, and economic development." European Economic Review 45, no. 4, 847-859.

Hsiao, C. (2003). Analysis of panel data. Cambridge: Cambridge university press.

James, A. (2015). "The resource curse: a statistical mirage?." Journal of Development Economics 114, 55-63.

Kim, D. H., and Lin, S. C. (2015). "Natural resources and economic development: new panel evidence." Environmental and Resource Economics 66, no. 2, 1-29.

Knack, S., and Keefer, P. (1995). "Institutions and economic performance: cross-country tests using alternative institutional measures." Economics \& Politics 7, no. 3, 207-227.

Koopmans, T. C. (1963). On the concept of optimal economic growth. Cowles Foundation Discussion 
Papers 163, Cowles Foundation for Research in Economics, Yale University.

Le Billon, P. (2001). "The political ecology of war: natural resources and armed conflicts." Political geography 20, no. 5, 561-584.

Loayza, N. V., and Ranciere, R. (2006). "Financial development, financial fragility, and growth.” Journal of Money, Credit and Banking 1051-1076.

Lucas, R. E. (1988). "On the mechanics of economic development." Journal of monetary economics 22, no. 1, 3-42.

Lujala, P., Gleditsch, N. P., and Gilmore, E. (2005). "A diamond curse? Civil war and a lootable resource." Journal of Conflict Resolution 49, no. 4, 538-562.

McKillop, A. (2004). "Oil price trends through 2004-2010." Petroleum World.

Mehlum, H., Moene, K., and Torvik, R. (2006). "Institutions and the Resource Curse." The Economic Journal 116, no. 508, 1-20.

Montinola, G. R., and Jackman, R. W. (2002). "Sources of corruption: A cross-country study." British Journal of Political Science 32, no. 1, 147-170.

North, D. (1990). Institutions, Institutional Change, and Economic Performance. Cambridge, Cambridge University Press.

North, D. C., and Thomas, R. P. (1973). The rise of the western world: A new economic history. Cambridge University Press.

Pedroni, P. (2000). "Fully Modified OLS for Heterogeneous Cointegrated Panels." Advances in Econometrics $15,93-130$.

Pedroni, P. (2001). "Purchasing Power Parity Tests in Cointegrated Panels." The Review of Economics and Statistics 83, no. 4, 727-731.

Pesaran, M. H. (2004). General diagnostic tests for cross section dependence in panels. CESifo Working Paper Series No. 1229.

Pesaran, M. H. (2006). "Estimation and inference in large heterogeneous panels with a multifactor error structure." Econometrica 74, 967-1012.

Pesaran, M. H. (2007). A "simple panel unit root test in the presence of cross-section dependence." Journal of Applied Econometrics 22, no. 2, 265-312.

Pesaran, M. H., Shin, Y., and Smith, R. P. (1999). "Pooled mean group estimation of dynamic heterogeneous panels." Journal of the American Statistical Association 94, no. 446, 621-634.

Pesaran, M. H., and Smith, R. (1995). "Estimating long-run relationships from dynamic heterogenous panels." Journal of Econometrics 68, 79-113.

Pesaran, M. H., and Tosetti, E. (2011). "Large panels with common factors and spatial correlation." Journal of Econometrics 161, no. 2, 182-202.

Raz, A. (2013). "The nexus between bank credit development and economic growth in Indonesia." DLSU Business \& Economics Review 23, 93-104.

Rigobon, R., and Rodrik, D. (2005). "Rule of law, democracy, openness and income: estimating the interrelationships." Economics of Transition 13, no. 3, 533-564.

Risse, T., and Sikkink, K. (1999). "The socialization of international human rights norms into domestic practices: introduction.” Cambridge Studies in International Relations 66, 1-38. 
Romer, P. M. (1986). "Increasing returns and long-run growth." The Journal of Political Economy 94, no. $5,1002-1037$.

Ross, M. L. (2001). "Does oil hinder democracy?.” World politics 53, no. 3, 325-361.

Ross, M. L. (2004). "What do we know about natural resources and civil war?." Journal of peace research 41, no. 3, 337-356.

Rufael, Y. (2009). "Re-examining the financial development and economic growth nexus in Kenya." Economic Modelling 26, 1140-1146.

Sachs, J. D., and Warner, A. M. (1995). Natural resource abundance and economic growth. National Bureau of Economic Research Working Paper No. 5398.

Sachs, J. D., and Warner, A. M. (1999). "The big push, natural resource booms and growth." Journal of Development Economics 59, no. 1, 43-76.

Sachs, J. D., and Warner, A. M. (2001). "The curse of natural resources." European Economic Review 45, no. 4, 827-838.

Samargandi, N., Fidrmuc, J., and Ghosh, S. (2015). "Is the relationship between financial development and economic growth monotonic? Evidence from a sample of middle-income countries." World Development 68, 66-81.

Smith, B. (2015). "The resource curse exorcised: Evidence from a panel of countries." Journal of Development Economics 116, 57-73.

Solow, R. M. (1956). "A contribution to the theory of economic growth." The Quarterly Journal of Economics 70, no. 1, 65-94.

Van Der Ploeg, F., and Poelhekke, S. (2010). "The Pungent Smell of "Red Herrings": Subsoil assets, rents, volatility and the resource curse.“ Journal of Environmental Economics and Management 60, no. 1, 44-55.

Van der Ploeg, F. (2011). "Natural Resources: Curse or Blessing?." Journal of Economic Literature 49, no. $2,366-420$.

Wei, S. J. (2006). "Connecting two views on financial globalization: Can we make further progress?." Journal of the Japanese and International Economies 20, no. 4, 459-481.

Wu, S.-Y., Tang, J.-H., and Lin, E. S. (2010). "The impact of government expenditure on economic growth: How sensitive to the level of development?." Journal of Policy Modeling 32, no. 6, 804-817.

Wurgler, J. (2000). "Financial Markets and the Allocation of Capital." Journal of Financial Economics 58, 187-214.

Yang, Y., and Yi, M. (2008). "Does financial development cause economic growth? Implication for policy in Korea." Journal of Policy Modeling 30 827-840.

Zhang, J., Wang, L., and Wang, S. (2012). "Financial development and economic growth: recent evidence from China." Journal of Comparative Economics 40, 393-412. 


\section{Appendix}

\section{Appendix A}

\begin{tabular}{|c|c|c|}
\hline Variable & Definition & Source \\
\hline $\begin{array}{l}\text { Gross domestic product per capita } \\
(\text { LnGDPC) }\end{array}$ & $\begin{array}{l}\text { GDP per capita is gross domestic product divided by midyear } \\
\text { population. GDP is the sum of gross value added by all resident } \\
\text { producers in the economy plus any product taxes and minus any } \\
\text { subsidies not included in the value of the products. }\end{array}$ & WDI (2017) \\
\hline Oil rent & $\begin{array}{l}\text { Difference between the value of crude oil production at world prices } \\
\text { and total costs of production. }\end{array}$ & WDI (2017) \\
\hline$Q O G$ & $\begin{array}{l}\text { Governance quality (QOG) (known as institutional quality), which } \\
\text { consists of corruption, law and order and bureaucracy quality } \\
\text { indicators. The mean of the three indicators ranges from } 0 \text { to } 1 \text {. A } \\
\text { score of } 0 \text { indicates the worst QOG, and } 1 \text { denotes the best QOG. }\end{array}$ & ICRG (2017) \\
\hline$C F C$ & $\begin{array}{l}\text { Gross fixed capital formation includes land improvements (fences, } \\
\text { ditches, drains, and so on); plant, machinery, and equipment } \\
\text { purchases; and the construction of roads, railways, and the like, } \\
\text { including schools, offices, hospitals, private residential dwellings, and } \\
\text { commercial and industrial buildings. According to the } 1993 \text { SNA, } \\
\text { net acquisitions of valuables are also considered capital formation. }\end{array}$ & WDI (2017) \\
\hline $\begin{array}{l}\text { General government final } \\
\text { consumption expenditure } \\
(\% \text { of } G D P)(G O V)\end{array}$ & $\begin{array}{l}\text { General government final consumption expenditure includes all } \\
\text { government current expenditures for purchases of goods and services } \\
\text { (including compensation of employees). It also includes most } \\
\text { expenditures on national defense and security, but excludes } \\
\text { government military expenditures that are part of government capital } \\
\text { formation. }\end{array}$ & WDI (2017) \\
\hline Population growth $(P G)$ & $\begin{array}{l}\text { Annual population growth rate for year } t \text { is the exponential rate of } \\
\text { growth of midyear population from year } t-l \text { to t, expressed as a } \\
\text { percentage. Population is based on the de facto definition of } \\
\text { population, which counts all residents regardless of legal status or } \\
\text { citizenship. }\end{array}$ & WDI (2017) \\
\hline Financial development index (FD) & $\begin{array}{l}\text { A principal component constructs using domestic credit provided by } \\
\text { private financial sector and broad money supply. }\end{array}$ & WDI (2017) \\
\hline Globalization (GLO) & $\begin{array}{l}\text { The KOF Globalization Index measures the economic, social and } \\
\text { political dimensions of globalization. }\end{array}$ & ICRG (2017) \\
\hline
\end{tabular}

